\title{
A FOTOGRAFIA NA PESQUISA EM EDUCAÇÃO
}

\section{LA FOTOGRAFÍA EN LA INVESTIGACIÓN EN EDUCACIÓN}

PHOTOGRAPHY IN EDUCATION RESEARCH

\author{
Olga Maria Botelho EGAS ${ }^{1}$
}

RESUMO: Este artigo apresenta a fotografia como procedimento artístico fundamental para a construção da visualidade contemporânea e suas implicações em sala de aula. Discute ainda como as imagens fotográficas tornam visíveis os problemas relacionados ao ensino e à aprendizagem. Discorre sobre usos e principais estruturas visuais das Metodologias Artísticas de Pesquisa baseadas na fotografia, propostas por Ricardo Marin Viadel e Joaquín Roldán (2012). O conhecimento visual produzido nessa pesquisa possibilita novos modos de contemplar e expor os fenômenos educativos.

PALAVRAS-CHAVE: Fotografia. Metodologias artísticas de pesquisa baseadas na fotografia. formação docente.

RESUMEN: Se presenta la fotografía como procedimiento artístico fundamental para la construcción de la visualidad contemporánea y sus implicaciones en clase. También se discute cómo las imágenes fotográficas hacen visibles los problemas relacionados con la enseñanza y el aprendizaje. Habla respecto a los usos y principales estructuras visuales de las Metodologías Artísticas de Investigación basadas en la fotografía, propuestas por Ricardo Marin Viadel y Joaquín Roldán (2012). El conocimiento visual producido en esta investigación posibilita nuevos modos de contemplar y exponer a los fenómenos educativos.

PALABRAS CLAVE: Fotografía. Metodologías artísticas de investigación basadas en la fotografía. Formación docente.

ABSTRACT: This article presents photography as a fundamental artistic procedure for the construction of contemporary visuality and its implications in the classroom. It also discusses how photographic images make visible the problems related to teaching and learning. It discusses uses and main visual structures of the Photography-Based Research Methodologies, proposed by Ricardo Marin Viadel and Joaquín Roldán (2012). The visual knowledge produced in this research allows new ways of contemplating and exposing educational phenomena.

1 Universidade Federal de Juiz de Fora (UFJF), Juiz de Fora - MG - Brasil. Professora Adjunta no Departamento de Educação da Faculdade de Educação. ORCID: <http://orcid.org/0000-0003-2295-959X>. E-mail: olga.egas@ufjf.edu.br 
KEYWORDS: Photography. Artistic research methodologies based on photography. Teacher training.

\section{Introdução}

Arte-educadora, desde sempre, reconheço que as transformações nas políticas públicas para a Educação, em especial as relacionadas ao ensino de arte, bem como as mudanças sociais e culturais contemporâneas, desafiam o espaço da educação e das formas de produção e aquisição de conhecimento. Essas mudanças propõem novos lugares para a educação, e diante delas, pergunto-me, qual educação? Como isso afeta o professor? Por que ainda não somos competentes na tarefa de relacionar o que se ensina na escola com o que se aprende fora dela?

Contemporaneamente, crianças, adolescentes e jovens, provavelmente, tem outra relação com as imagens e frequentemente se reconhecem através das imagens. Podemos afirmar que se configuram como a geração visual na escola. Familiarizadas com imagens de todos os tipos, as crianças e adolescentes assistem ao mundo pela telinha do celular, do tablet, da TV, do monitor, do cinema, explorando os editores de imagens e selfies sem fim. Estão absolutamente à vontade com o universo da produção e da fruição das imagens. Curiosamente, os professores, imersos na mesma visualidade, poucas vezes produzem imagens autorais para dialogar com os estudantes, talvez, resistindo em estabelecer conexões entre a visualidade contemporânea e a sala de aula.

Observe-se que ainda hoje, a arte na escola ganha espaço e visibilidade, entre as demais disciplinas e a direção, em geral, quando 'ilustra' e faz a festa durante os eventos previstos no calendário escolar. As datas comemorativas, os painéis decorados com personagens da mídia, a história da arte cronológica, bem como os artistas consagrados, têm presença garantida no cotidiano escolar em detrimento das imagens produzidas pelos alunos. Cópias, releituras, o bom e o bonito - mais do mesmo. As datas comemorativas marcam o currículo escolar, sempre temático, há tempos, como habitus, a despeito do contexto de mudanças em que vivemos. Sempre as mesmas datas, sempre 'comemoradas' do mesmo jeito. Por que repetimos na escola as efemérides históricas e os festejos religiosos, reproduzindo-os com apelo meramente comercial, reforçando preconceitos e estereótipos? Que curriculum escolar nós estamos construindo? O que os alunos gostariam de comemorar, se verdadeiramente, contribuíssem com a tessitura dos saberes escolares? 
Como escapar dos conteúdos rotinizados e reinventar outras práticas para dar voz e força aos alunos, aos professores, à arte e à cultura na escola?

Sabemos que a desconfiança histórica entre os campos da arte e da ciência repercutem na Escola, apesar de todas as pesquisas sobre a importância da arte na escola e nos processos de aprendizagem. No entanto, a arte provoca/constrói/revela um campo de conhecimentos de natureza distinta dos saberes científicos tradicionais, valorizados na escola, quando as questões são as avaliações do ensino e aprendizagem vinculados ao vestibular e o Exame Nacional para o Ensino Médio - ENEM, e a inserção no mercado profissional.

Quando provoca/constrói/revela seu campo de conhecimento, a Arte na escola possibilita compreensões outras sobre si e o mundo, apostando na liberdade e na multiplicidade de fazer-se em sala de aula, isto é, tecendo diálogos internos capazes de ampliar, inquietar e estabelecer novas relações através da sensibilidade, da delicadeza e da disponibilidade para tocar o outro e fazê-lo desaprender o já conhecido. Tal ambiência é improvável diante da oferta reducionista e profissionalizante imposta pelo Governo Federal, através de Medida Provisória, como a Reforma do Ensino Médio, por exemplo.

Pode a escola nutrir-se da contemporaneidade, das culturas e da arte para produzir saberes com novos sabores? Como arquitetar futuros educadores potentes para lidar com os acontecimentos, com a complexidade da arte e da cultura e com os novos campos de conhecimento dos tempos que correm? Quais os deslocamentos necessários na formação inicial de professores para mantê-los em estado de invenção e autores reflexivos de sua própria prática?

\section{As imagens fotográficas na Escola}

No texto Territórios de las metodologias artísticas de investigación com un fotoensayo a partir de Buñuel, os professores Marin e Roldán (2012, p. 130) considerando a onipresença dos telefones celulares com câmera entre os jovens alunos, defendem o trabalho com a fotografia digital, ponderando que: 1) A criação de imagens deve ser a atividade fundamental nas artes visuais; 2) A fotografia digital oferece facilidade na obtenção de inúmeras imagens, agilidade na visualização e baixo custo, viabilizando a discussão sobre conceitos fotográficos e a qualidade da produção e, 3) Na sociedade atual, 
a fotografia digital se transformou em um meio de produção de imagens e os professores precisam se apropriar dele em profundidade.

Como afirma Roldán (2012, p. 45),

\begin{abstract}
A fotografia foi considerada, quase desde seu início, reflexo objetivo da realidade e, por conseguinte tecnicamente útil em certas tarefas menores da atividade cientifica, como a ilustração de textos, a documentação de sucessos ou fenômenos, fonte de dados primários ou divulgação de resultados.
\end{abstract}

Tais usos ainda continuam presentes, tanto nas pesquisas quanto na prática docente. Entretanto, na contemporaneidade, os valores de registro, verdade, identidade, memória e arquivo inicialmente atribuídos à fotografia analógica estão sendo substituídos e/ou ampliados. Na sociedade que privilegia a informação como mercadoria, a urgência e a imediatez, as redes de informação e a globalização, a fotografia digital utiliza a tela como superfície e sua impressão sobre papel não é mais condição indispensável para a existência da imagem. Nesse sentido, "a foto digital é uma imagem sem lugar e sem origem, desterritorializada, não tem mais lugar porque está em todas as partes", afirma o professor e artista Joan Fontcuberta em seu livro La Cámara de Pandora (2015, p. 13). Se antes, a fotografia analógica era tida como uma escritura do seu tempo, hoje a fotografia digital assume a linguagem do Homo Photographicus, expressão criada por Fontcuberta para traduzir a era dos selfies.

No início dos anos 2000, lecionando na graduação em Design, experimentei pela primeira vez a fotografia digital como estratégia de aprendizagem, considerando que as câmeras digitais da faculdade poderiam ser emprestadas aos alunos, durante o período da aula e que o uso do disquete para arquivo não traria custo para a iniciativa. A disciplina, no primeiro semestre do curso, se chamava Linguagem Visual, com foco na análise formal da composição visual. Em pequenos grupos, os alunos eufóricos com a nova tecnologia saíam a campo com a câmera digital e um disquete para criar composições com os elementos encontrados no espaço e registrá-los fotograficamente. Através do projetor e do computador da sala, os resultados, obtidos nos exercícios práticos, eram apresentados na aula seguinte, discutidos coletivamente, implicando em outra acepção para a sintaxe visual, tanto para alunos como para mim.

Quase duas décadas depois, a fotografia digital estabelece novos modos de construir e compreender a realidade. Em nossa cultura a imagem é tudo: deslumbramento, verossimilhança, persuasão e consumo. Na era das imagens, há mais informação em nosso 
meio do que aquela que "vemos". Refletir sobre essas questões pode ser uma instigante e saborosa aventura pedagógica para além dos muros da escola. Entretanto, a avalanche de imagens a que somos submetidos diariamente não nos leva a ver melhor... Curiosamente, para esta geração visual, a imagem pode ser tudo e nada!

Figura 1: Citação visual literal

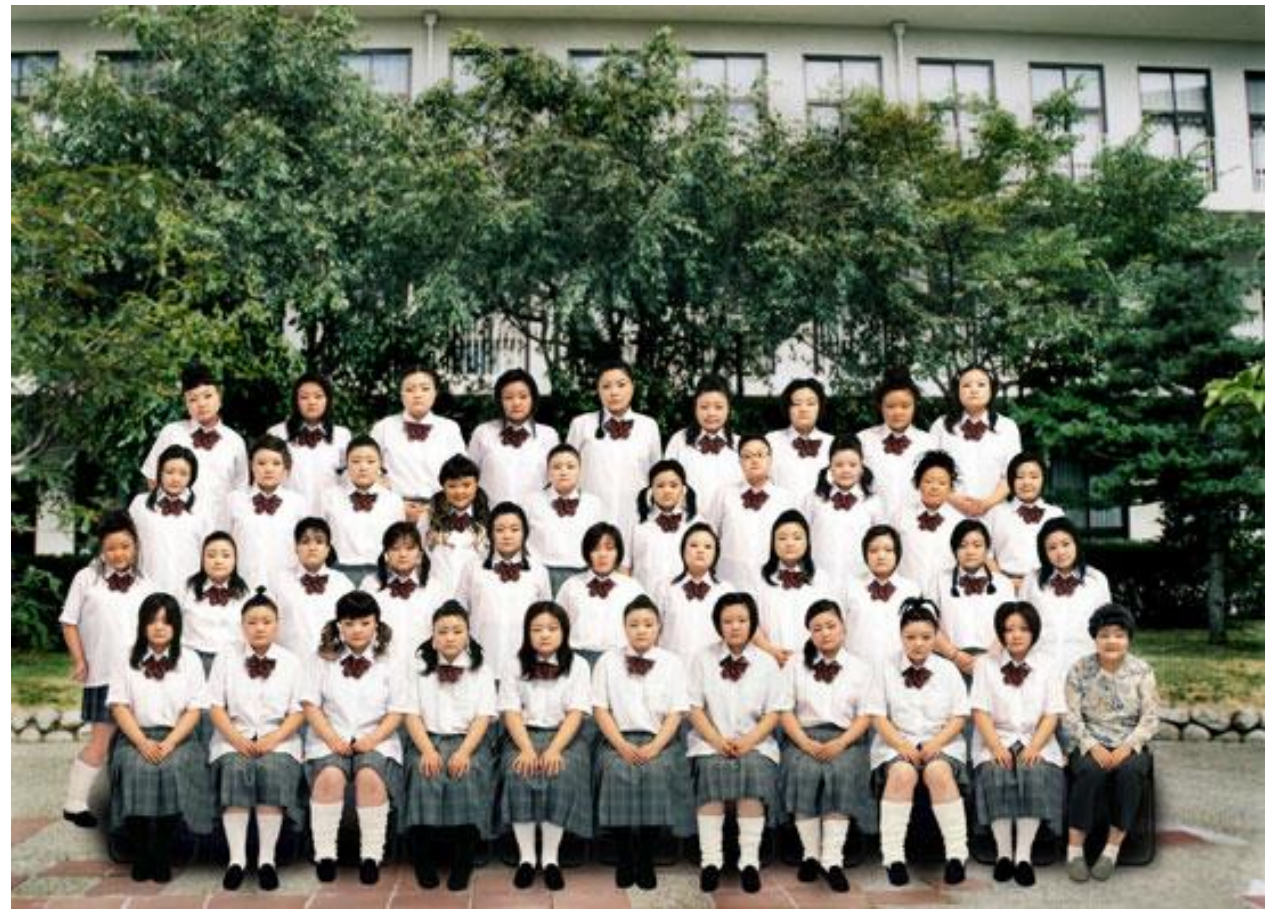

Fonte: Sawada (2006) - Fotografia digital.

School Days é um livro de fotografias produzidas pela artista japonesa Tomoko Sawada. O formato se assemelha aos livros de bolso, em pequenas proporções e apresenta apenas dez imagens impressas sobre papel encorpado. São retratos de grupos de estudantes, na pose típica de encerramento do ano letivo. Sawada altera a composição fotográfica, incluindo sua própria imagem, em diferentes caracterizações, sobre o rosto das estudantes e da professora.

As fotografias apresentadas nesta publicação japonesa ampliam a compreensão sobre as questões de gênero e identidade escolar de alunas(os) e professores(as). Questiono como a discussão sobre essas identidades, tão presentes em nosso cotidiano, ganha novos aportes através da observação do processo criativo da artista? Como seria, por exemplo, a imagem final das identidades das escolas brasileiras no sudeste, no centro ou no norte do país? Quais as repercussões dessas imagens no senso de pertencimento dos estudantes e 
como isso afeta os vínculos entre eles e a escola, o ensino e a aprendizagem? Poderíamos rever nossa própria docência a partir das imagens fotográficas?

Seguindo a ideia de "dar a ver", poderíamos examinar como a escola se apresenta em sua versão oficial, no site institucional, nos folhetos publicitários e na fachada do prédio que habita e, simultaneamente, confrontar como os alunos fazem sua versão oficiosa da escola nas redes sociais e nos. Se por um lado, a escola se apresenta visualmente 'em fileiras', organizada e higienizada, por vezes, em composição similar à fotografia acima, da artista Sawada, Por outro lado, com os alunos acontece o inverso, a ordem e a gestualidade são outras, irreverentes, espontâneas e informais. O que podemos aprender da escola com os estudantes da "geração visual" e as imagens que realizam na/da escola?

\section{Metodologias artísticas de pesquisa em educação}

A Pesquisa Educacional baseada em Artes tem sido objeto de estudo em diferentes países, inclusive no Brasil, interessados nas possíveis inter-relações entre pesquisa cientifica e criação artística. Segundo Belidson Dias (2016, p. 7), professor no Departamento de Artes Visuais da Universidade de Brasília, UnB:

Existe uma tendência recente por parte de alguns estudiosos de denominar "Pesquisa" (Research) aqueles estudos com maior ênfase em metodologias quantitativas para a produção do conhecimento e "investigação" (Inquiry) como aqueles voltados para questões qualitativas e que produzem, sobretudo, saberes, além de conhecimentos. Outros consideram que a "Pesquisa" é hierárquica à "investigação", sendo esta somente etapa daquela.

De nossa parte, esclarecemos que adoção do termo "pesquisa", ao longo deste trabalho, se justifica pela afinidade metodológica e à tradução dos termos realizada por Ricardo Marin (2016, p. 97), no texto Las teorías educativas también se hacen com imágenes: pesquisa baseada em artes visuais.

Quadro 1: Equivalência do uso da terminologia em três idiomas

\begin{tabular}{|c|c|c|}
\hline Español & Português & Inglés \\
\hline Educación Artística & Arte-Educação & Art Education \\
\hline Investigación Basada en Arte & Pesquisa Baseada em Arte & Art Based Research \\
\hline Investigación Artística & Pesquisa Artística & Artistic Research \\
\hline
\end{tabular}




\begin{tabular}{|c|c|c|}
\hline $\begin{array}{c}\text { Metodologías de } \\
\text { Investigación Educativa } \\
\text { Basadas en Artes Visuales }\end{array}$ & $\begin{array}{c}\text { Metodologias de Pesquisa } \\
\text { Educativa Baseadas em } \\
\text { Artes Visuais }\end{array}$ & $\begin{array}{c}\text { Visual Arts Based } \\
\text { Educational Research } \\
\text { Methodologies }\end{array}$ \\
\hline $\mathrm{A} / \mathrm{r} /$ tografía & $\mathbf{A} / \mathbf{r} /$ tografia & $\mathrm{A} / \mathrm{r} /$ tography \\
\hline
\end{tabular}

Fonte: Marin (2012)

As Metodologias Artísticas de Pesquisa têm origem nas Metodologias Qualitativas, diferenciando-se destas, ao incluir as linguagens musicais, visuais, corporais e áudio visuais em seus dados, argumentos e conclusões. Como afirma Marin, as Metodologias Artísticas de Pesquisa,

\begin{abstract}
Aproveitam dos conhecimentos profissionais de diferentes especialidades artísticas (arquitetura, cinema, desenho, dança, fotografia, música, novela, performance, poesia, teatro, vídeo, etc.) tanto para o planejamento e definição dos problemas como para a obtenção dos dados, a elaboração dos argumentos, a demonstração de conclusões e a apresentação dos resultados finais. As Metodologias Artísticas de Pesquisa são uma nova forma de fazer pesquisa em ciências humanas e sociais que trabalham de forma paralela e semelhante à criação artística. Surgiram nos últimos anos do século XX no campo da Educação Artística e atualmente estão sendo utilizadas em ampla variedade de disciplinas, tais como na antropologia, na economia, na enfermagem, na psicologia e no trabalho social, [...] São um modo polêmico e controvertido de fazer pesquisa que se encontra em estágio de desenvolvimento. Sua situação é tão atrevida e comprometedora porque seus dois principais objetivos são enriquecer as investigações sociais e educacionais com a experiência das Artes e fazer com que as Artes se interessem pelos problemas da investigação social e educativa. (MARIN, 2012, p. 16).
\end{abstract}

Unindo a investigação científica e a criação artística, utilizando-se de mestiçagem, simbiose e fusão entre os territórios do conhecimento humano, as Metodologias Artísticas de Pesquisa na Educação podem produzir resultados frutíferos e têm como alicerces teóricos as publicações de Barone e Eisner (2012), Eisner (2008) e Marin Viadel (2005). A profícua parceria, entre os pesquisadores Tom Barone e Elliot Eisner, contribuiu significativamente para ampliar as pesquisas educacionais com base em produções artísticas.

A utilização de métodos quantitativos, qualitativos e artísticos numa mesma pesquisa, cada qual com seus propósitos, torna-se uma adequada combinação que possibilita uma rica investigação dos problemas específicos do ensino e da aprendizagem das artes e das culturas visuais. A presença das linguagens artísticas e a qualidade artística e estética das imagens combinadas entre si, estabelecem e definem melhores perguntas 
para os problemas educativos. Talvez, seja indispensável ao pesquisador descobrir problemas, situações, detalhes que não possam ser expressos por palavras, mas ao mesmo tempo, transformem o ordinário em extraordinário, de tal modo que os problemas educativos "dizem" dos dados, ideias, argumentos e conclusões, fundamentalmente através de imagens.

Figura 2: Foto-Ensaio - O corpo que desenha
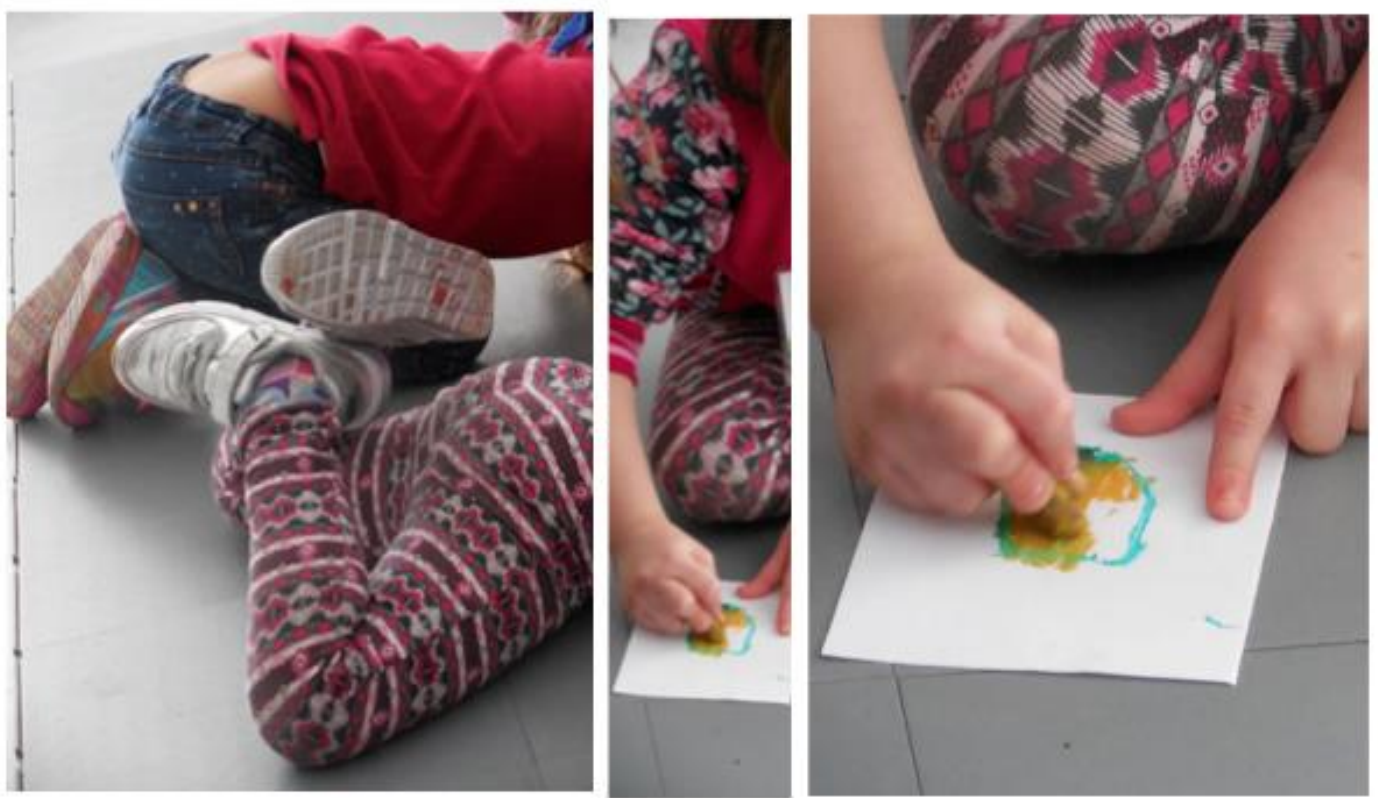

Fonte: Acervo pessoal - Composto por duas fotografias digitais

No campo da Arte-Educação, frequentemente, encontramos pesquisas acadêmicas relacionadas aos problemas de ensino e aprendizagem da arte, nos quais as imagens apenas ilustram os resultados dos trabalhos artísticos realizados por alunos, quando sujeitos da investigação. Nesse caso, não se trata propriamente de uma pesquisa baseada em imagens, mas de usar as imagens com uma finalidade ilustrativa.

Eliot Eisner, professor e pesquisador renomado da University Stanford, em seu livro, publicado em 2004, El arte y el educación de la mente, nos ensina que "a escolha de uma abordagem para o estudo do mundo não é apenas uma escolha do que se pode dizer sobre esse mundo, mas também o que se quer e se é capaz de ver. Métodos definem as estruturas através das quais nós interpretamos o mundo.” (EISNER, 2004, p. 262). Portanto, independente da abordagem, o método de pesquisa define: quais dados são 
necessários, como devem ser obtidos, organizados, classificados e sintetizados. Definem resultados e significados; atribuem confiabilidade e segurança e, revelam erros e acertos.

\section{Metodologias artísticas de pesquisa baseada na fotografia}

Nesse sentido, Marin Viadel e Roldán (2012) questionam como ver (literalmente) melhor os problemas educacionais; como olhamos (visualmente) esses problemas e como podemos imaginar novas soluções educacionais para o pleno desenvolvimento pessoal e social. Para esses autores, "uma pesquisa educacional baseada na fotografia é aquela que utiliza imagens e os processos fotográficos para indagar sobre os problemas relacionados com o ensino e a aprendizagem" (2012, p. 42).

Figura 3: Foto-Ensaio - Espaço educativo: o museu
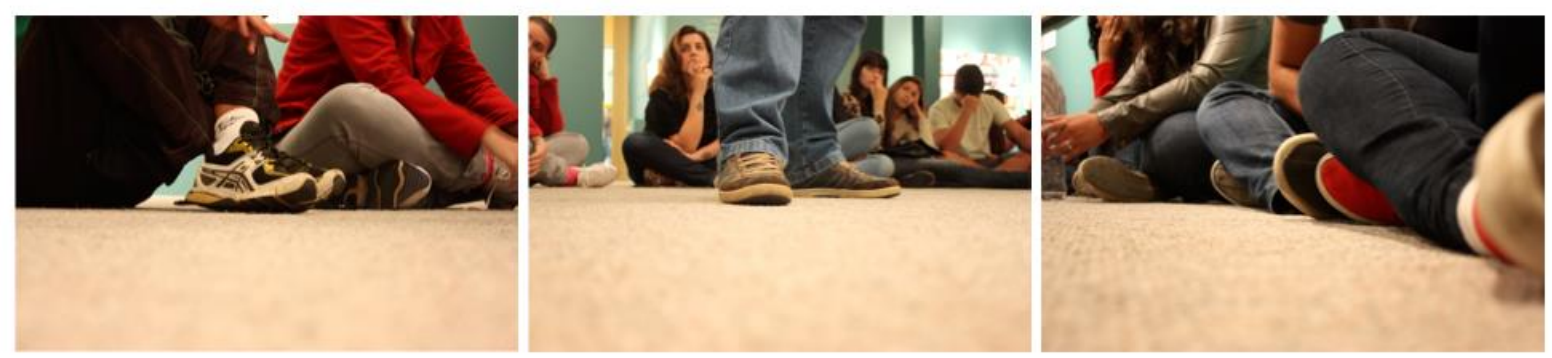

Fonte: Acervo pessoal

Os autores ainda complementam que metodologicamente, há duas estratégias recorrentes entre as pesquisas que utilizam imagens fotográficas: a primeira considera a fotografia como mero instrumento documental - no qual uma imagem é apenas um dado e, a segunda, informa que a fotografia é um modelo de pensamento visual - a imagem visual é uma ideia! Desse modo, as imagens fotográficas utilizadas na Pesquisa Educacional Baseada nas Artes Visuais descrevem, analisam e interpretam os processos e as atividades educativas e artísticas; constituem um meio de representação do conhecimento; organizam e demonstram ideias, hipóteses e teorias tal como as outras formas de conhecimento, além de proporcionar informação estética desses processos, objetos ou atividades.

No texto Las metodologías artísticas de pesquisa basada en la fotografia, Roldán define que:

Uma metodologia de pesquisa fotográfica baseada nas artes usa as qualidades estéticas fotográficas como instrumento fundamental de investigação. Esta pesquisa será educativa quando seus métodos e 
objetivos se apliquem à resolução ou planejamento de problemas no campo da educação. [...] $\mathrm{O}$ que caracteriza o trabalho das pesquisas fotográficas é precisamente que trabalham a descrição, a análise e a geração de novas situações que possam ser vistas de outro ângulo. (ROLDÁN. 2012, p. 56).

Figura 4: Foto-Ensaio - Espaço educativo: a aula

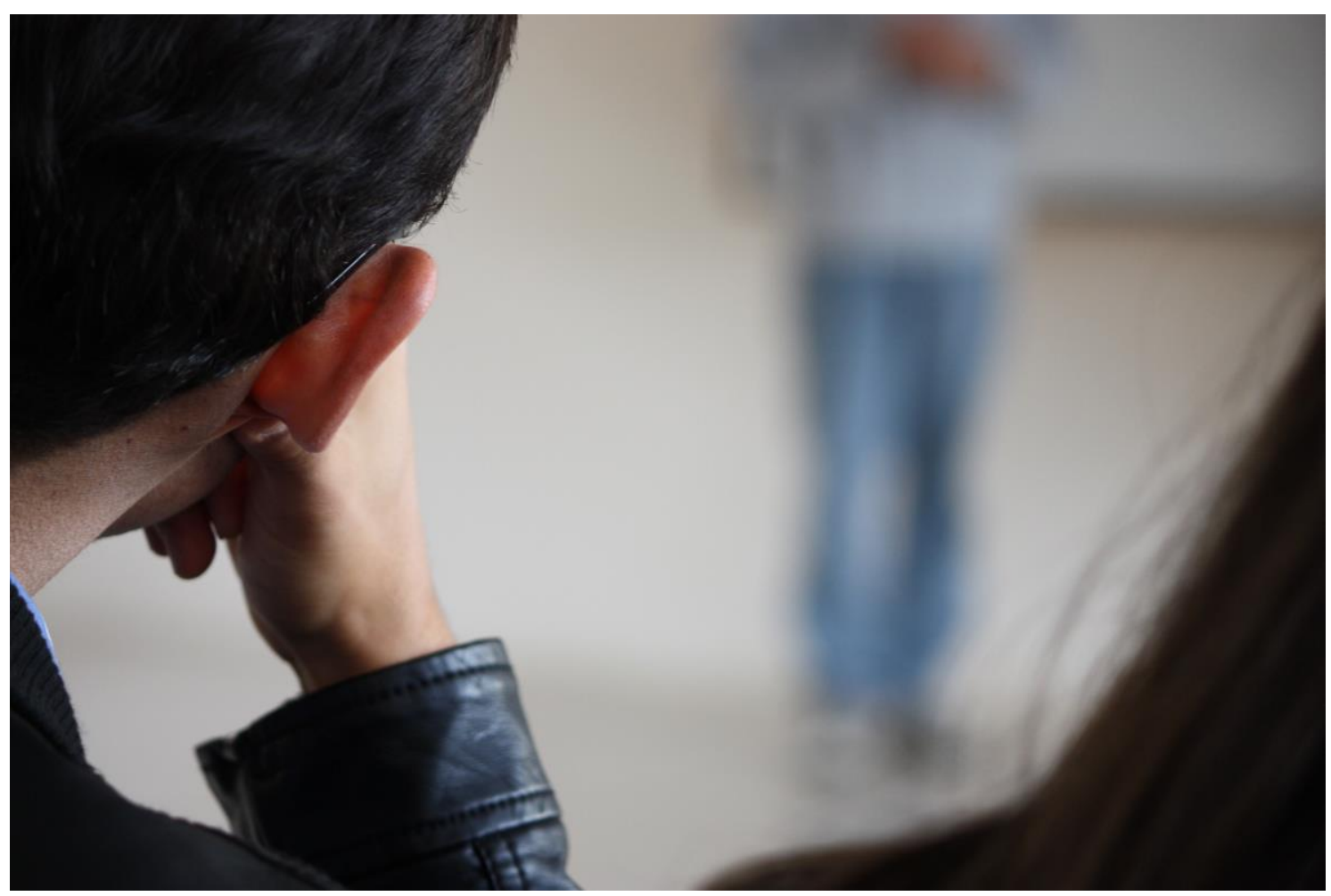

Fonte: Acervo pessoal

Os autores defendem a fotografia como instrumento de pesquisa e reconhecem a importância da identificação específica e da organização das estruturas visuais. Sobre isso MARIN (2012, p. 244) pontua os cuidados necessários com as imagens em uma pesquisa educacional, aqui sintetizada:

Não deve ser uma mera acumulação ou sucessão de imagens, assim como um texto não é uma simples sucessão de frases e parágrafos. Equilíbrio, ritmo, organização cadenciada entre as partes e o todo implica na qualidade da pesquisa.

Explicitar em todas as imagens o tipo de estrutura visual utilizada: Fotografias Independentes, Séries Fotográficas, Foto Ensaios, etc. Apesar de parecer prolixo e redundante, oferece clareza, facilita a interpretação e a valorização adequada.

Considerar a quantidade de imagens visuais e sua articulação narrativa sob a responsabilidade do autor e não de um designer gráfico. 
A qualidade das imagens fotográficas é muito importante, por isso o cuidado redobrado com a publicação e exibição das imagens, sejam elas isoladas ou em conjunto, considerando tamanho, contraste, coerência cromática, sequência narrativa, etc.

As imagens devem ser obras originais do autor da investigação, ou de pessoas que tenham participado do processo ou são citações visuais que devem ser explicitadas. Estas podem reproduzir a totalidade de uma imagem ou ser um fragmento, devidamente identificadas, com autoria, data, título e técnica ou materiais e se for pertinente, seu tamanho e duração.

Uma citação visual pode reproduzir a totalidade de uma imagem ou seu fragmento, desde que indicado explicitamente. Há que se identificar sempre, de forma inequívoca, todas e cada uma das imagens que a constituem.

Para os autores, a credibilidade de uma fotografia não está na representação da realidade diante da câmera, mas na amplitude e clareza dos conceitos que expressa. E para assegurar tal clareza, os cuidados relatados acima são fundamentais.

Outro aspecto característico da Metodologia Artística de Pesquisa baseada na Fotografia é a forma como as imagens descrevem, analisam e geram situações que podem ser vistas por outros ângulos, propondo novos modelos de visualização da complexidade do conjunto da cultura material e/ou de um problema educacional. Segundo Roldán (2012, p. 54), a opção por "pesquisar através de imagens fotográficas é que sem elas não poderíamos elaborar as ideias sobre educação que somente elas nos proporcionam".

Ao utilizar as imagens e os processos fotográficos nas pesquisas sobre educação, intencionamos questionar os problemas relacionados ao ensino e à aprendizagem. As imagens possibilitam a organização e a demonstração de ideias, hipóteses e teorias de modo equivalente às outras formas de conhecimento e oferecem informações estéticas desses processos, objetos e atividades.

Mas, afinal, como definir, descrever, documentar e concluir visualmente? No texto Estructuras narrativas y argumentales en investigación: Fotografias Independentes, Séries Fotográficas y FotoEnsayos, Marin e Roldán (2012, p. 67), descrevem os sete conceitos que sistematizam o uso de imagens na pesquisa. As estruturas visuais denominadas Fotografia Independente, Foto-Discurso, Série Fotográfica, Foto-Ensaio, Foto Resumo, Foto Conclusão e Citação Visual, "cumprem funções distintas, seja uma descrição ou uma comparação, seja uma argumentação ou uma demonstração, e todas devem ser adequadas aos requisitos e critérios de qualidade de uma pesquisa artística e educativa", afirmam os autores. Porém, reconhecem que estas definições não são herméticas e acreditam que seu uso possibilitará revisões e ajustes futuros. 
Ao selecionar os instrumentos visuais da pesquisa, precisamos considerar quais são os elementos do nosso interesse. Quais as variáveis e como podem ser arranjadas, quais as estratégias úteis e por fim, qual a técnica fotográfica mais adequada. Então, a utilização da fotografia na pesquisa pressupõe tomar decisões sobre: 1) o referente (objeto de pesquisa); 2) como fazer (quais as ações, em qual tempo, etc.); 3) contexto visual (onde, como); 4) revelar visualmente sua mirada de pesquisador e, 5) colocar em dúvida aquilo que vê (ponto de vista crítico).

Figura 5: Foto-Ensaio - Espaço educativo: a sala de aula.
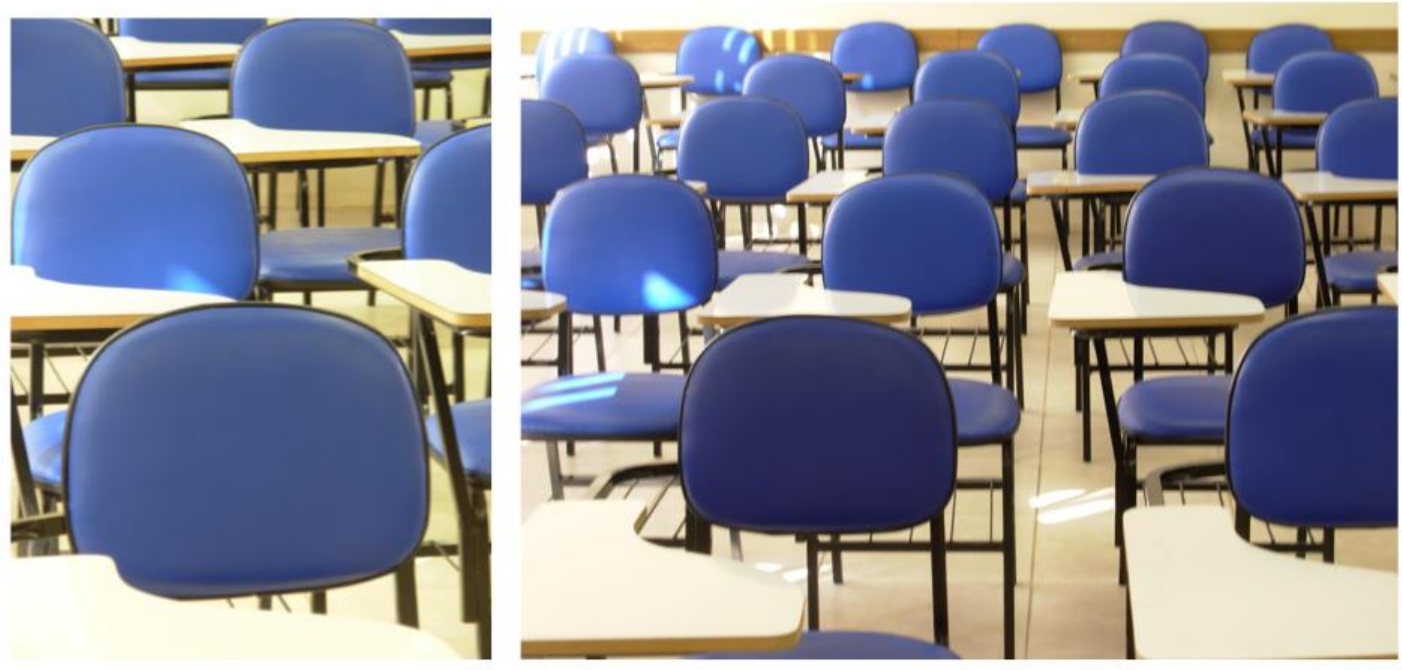

Fonte: Acervo pessoal

\section{Considerações finais}

A Metodologia Artística de Pesquisa baseada na Fotografia estabelece, assim, outro paradigma em relação à potência das imagens fotográficas na pesquisa em Educação. $\mathrm{O}$ pensamento fotográfico, organizado em séries fotográficas, fotos-ensaios, fotos-discursos, fotocollage, entre outros, requer uma intenção e um plano de trabalho próprio dos processos investigativos e, simultaneamente, coloca o pesquisador em estado de invenção atento ao seu próprio processo de criação, a multiplicidade de tempos, espaços e perspectivas da Educação. A dimensão artística na pesquisa em Educação, possibilita novas interpretações e gera novas perguntas de uma forma visual. 
Decorrem deste ponto alguns questionamentos para o campo da Educação: um texto verbal sobre os problemas educacionais pode ser suficientemente esclarecedor e provocativo para garantir que o leitor, como, por exemplo, um professor na sua formação inicial, adquira conhecimentos significativos sobre tais problemas? É possível fazer uma pesquisa educacional sem "dar a ver" a escola? Ou, de outro modo, podemos dizer da educação sem mostrá-la? Poderíamos estudar a Educação em profundidade através de suas imagens, descrevendo-a, analisando-a e gerando novas possibilidades para solucionar os problemas, sob o ponto de vista oferecido pela imagem?

Figura 6: Foto-Ensaio - Compartilhamentos.
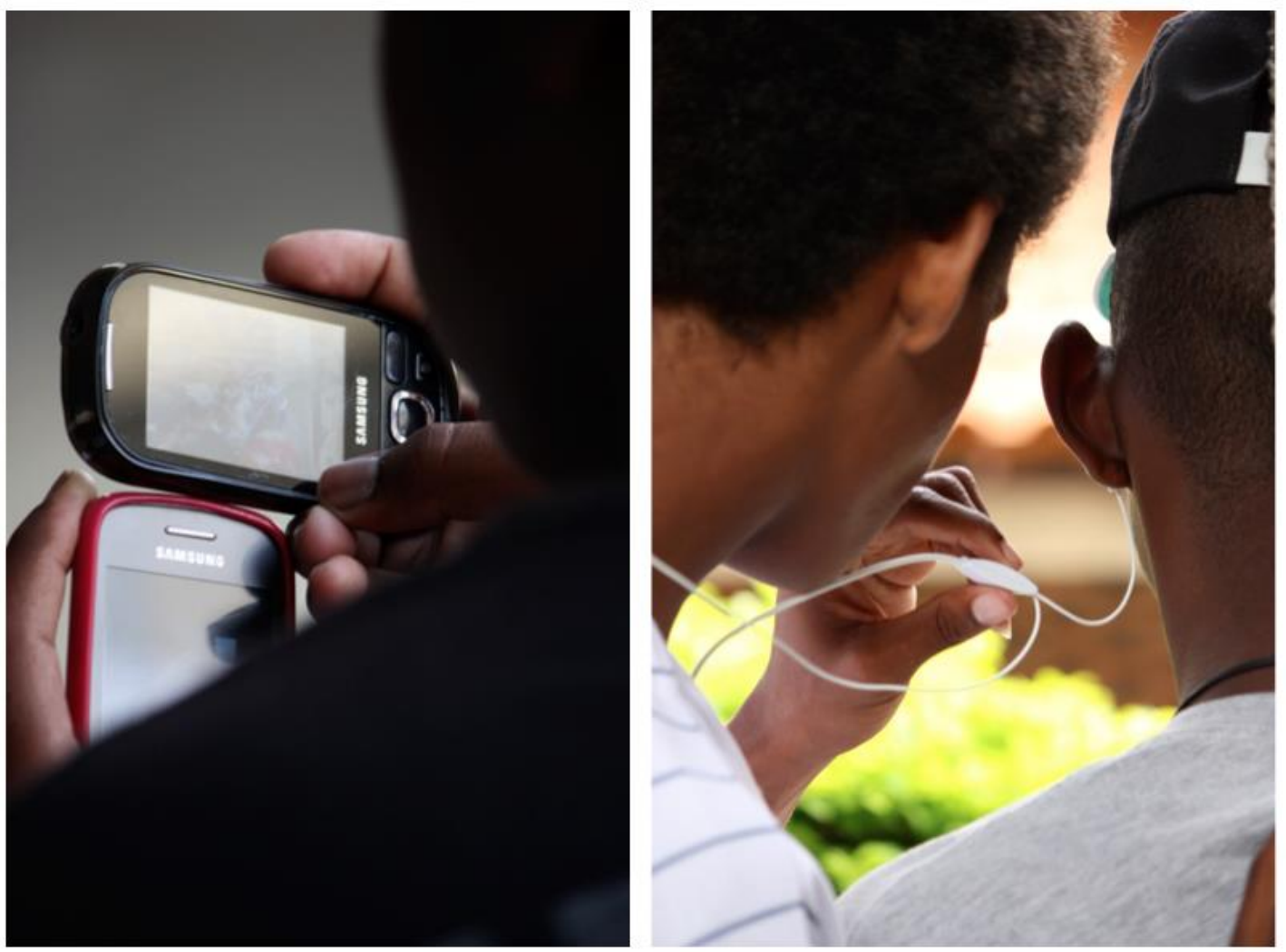

Fonte: Acervo pessoal

\section{REFERÊNCIAS}

BARONE, T.; EISNER, E. Arts Based Research. London: SAGE, 2012.

DIAS, B. Investigação Baseada em Arte em tempos de mudanças na Arte Educação. In: VENTURELLI, S. ROCHA, C. (org). Mutações, confluências e experimentações na Arte e Tecnologia. Brasília: Editora PPG-ARTE/UNB, 2016. 
EISNER, E. E. El arte y el educación de la mente. Barcelona: Paidós, 2004.

EISNER, E. Arts and knowledge. In: KNOWLES, Gary J. ARDRA, Cole L. Handbook of the Arts in qualitative research. Londres: Sage, 2008.

FONTCUBERTA, J. La câmara de Pandora: la fotografí@ despues de la fotografia. Barcelona: Gustavo Gili, 2015.

MARIN VIADEL, R. (org). Investigación en Educación Artistica: temas métodos y técnicas de indagación, sobre el aprendizaje y la ensenñza de las artes y culturas visuales. Granada: Universidad de Granada y Universidad de Sevilla. 2005.

MARIN VIADEL, R. Territórios de las Metodologias Artísticas de Investigación com un fotoensayo a partir de Buñuel. In: MARIN VIADEL, R.; RÓLDAN, J. Metodologías Artísticas de Investigación em Educación. Málaga, Espanha: Ediciones Aljibe, 2012

MARIN VIADEL, R.; RÓLDAN, J. Estructuras narrativas y argumentales en investigación: Fotografias Independientes, Series Fotográficas y FotoEnsayos. In: MARIN VIADEL, R.; RÓLDAN, J. Metodologías Artísticas de Investigación em Educación. Málaga, Espanha: Ediciones Aljibe, 2012.

MARIN VIADEL, R. Las teorías educativas también se hacen com imágenes: pesquisa baseada em artes visuais. Anais... II Seminário Internacional: formação de educadores em arte e pedagogia. Universidade Presbiteriana Mackenzie. São Paulo: Terracota, 2016.

ROLDÁN, J. Las Metodologias Artisticas de Investigación basadas en la fotografia. In: ROLDÁN, J.; MARIN, R. Metodologías artísticas de investigación en educación. Archidona, España: Aljibe, 2012.

SAWADA, T. School Days. Kyoto: Seigensha Art Publishing. 2006.

\section{Como referenciar este artigo}

EGAS, Olga Maria Botelho. A Fotografia na pesquisa em Educação. Revista IberoAmericana de Estudos em Educação, Araraquara, v. 13, n. 3, p. 953-966, jul./set., 2018. E-ISSN: 1982-5587. DOI: 10.21723/riaee.v13.n3.2018.10871

Submetido em: 05/01/2018

Aprovado em: 10/05/18 